\title{
文献調査に基づく仕上塗材・塗料の耐候性評価に関する提案 PROPOSAL ON WEATHERABILITY EVALUATION OF COATING MATERIALS BASED ON LITERATURE SURVEYS
}

\author{
長谷川 拓哉*, 千歩 修**, 福山智子*** \\ Takuya HASEGAWA, Osamu SENBU and Tomoko FUKUYAMA
}

\begin{abstract}
In order to evaluate the durability of coating materials, estimation equation of the gloss retention was proposed in previous study. This paper reported the applicability of the proposed equation to outdoor exposure test results and accelerated weatherability test results obtained from literature surveys. It was high correlation between estimated results and measured results of gloss retention. Obtained outdoor exposure results showed that the type of coating materials were mainly affected on the weatherability. It was proposed estimation method of gloss retention in coating materials exposed to outdoor from accelerated weatherability test results.
\end{abstract}

Keymords: Coating materials, Weatherability ,G loss retention , Outdoor exposure test, Accelerated weathering test 塗材，而猴性，光沢保持率，屋外暴露試験，促進而候性試験

\section{1. はじめに}

建築用仕上塗材 - 塗料の耐久性に関し，促進耐候性試験と屋外暴 露試験との関係が議論されることが多い例えば 1)。しかし，促進耐候 性試験に用いられる光源と太陽光では分光分布が異なっており，紫 外線による樹脂骨格の破壞作用が化学成分によって異なることが指 摘されている 2)。促進耐候性試験方法, 樹種によってその促進倍率 が異なる場合 1)もあり, 建築用仕上塗材・塗料の耐候性を評価する 上では，屋外暴露試験によることが基本と考えられる。

一方で，両者には相関が認められることが報告されているととも に例えば1), JIS A 6909 では品質規格として, 促進耐候性試験結果に 基づき耐候形 1 3 種の区分が規定されており, 屋外暴露環境下の耐 候性の目安としていると考えられる。しかし, 前述の理由で, 定量 的に「促進耐候性試験は屋外暴露の○○年に相当」とは一概に言え ず，耐候性の大小比較の際の定性的な目安とされてきた。定性的な 評価に留まってきたのは, 塗膜劣化の進行について定式化されてい ないことが一因と考えられる。劣化進行の定式化は多くの研究者が 検討しており, 例えば近藤ら ${ }^{3)}$ は, 建築物の調査に基づき, 線形, 指数, 対数等の回帰式を検討し, 耐候形の区分に使用される指標で ある光沢保持率については, 対数関数で表すのが適当であるとして いる。著者らは, 小池・田中らの防水層の耐候性に関寸る研究 ${ }^{4)}$ に 基づき, 屋外暴露環境下の光沢保持率低下を表す式を提案している 5)。しかし, 限られたデータでの検討であり, 適用性の検討は十分 とはいえない。
本研究では, 建築用仕上塗材・塗料を対象として, 札幌市におけ る 13 年の屋外暴露試験より光沢保持率低下を検討するとともに, 促進耐候性試験結果および屋外暴露試験結果を報告している文献調 查を行い，提案式の適用性の検討を行う。その上で，塗膜の劣化進 行に関して促進耐候性試験と屋外暴露試験の関係を検討し, 両者を 結びつける考え方を提案することを目的としている。なお，本研究

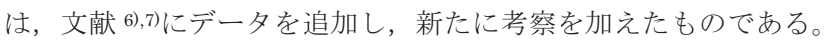

\section{2. 検討の概要}

\section{1 実験および文献調査の概要}

実験の概要を表 1 に示す。各種仕上塗材・塗料を $\phi 10 \times 3.5 \mathrm{~cm}$ の W/C57.5\%としたコンクリート試験体に施工したものを北海道大学 工学部（札幌市）に屋外暴露し，6，8.5，13 年時に色差および光沢 度の変化を測定した。色差は色彩色差計を用い $\mathrm{L}^{*} \mathrm{a} * \mathrm{~b}$ *表色系にて 測定した。光沢度は $60^{\circ}$ の光沢度計を用いて測定した。なお，既報 8)において同じ仕上塗材・塗料を濾紙に施工した試験体について, JIS A 1415 に準拠したサンシャインウェザーメータ（以下 SWM） 試験を 2500 時間行い，色差および光沢度の変化を報告している。

文献調查の概要を表 2 に示す。文献調查は, 本学会構造系論文集, 技術報告集，大会梗概集より，建築用塗料，仕上塗材を対象として， 促進耐候性試験および屋外暴露試験を行っているもの 1),5),8 〜 25)を収 集した。なお，促進耐候性試験は，SWM 試験およびキセノンラン プ法の結果を収集した。ここで，同じ樹脂系や仕上げ種類でも耐候

\footnotetext{
* 北海道大学大学院工学研究院空間性能システム部門 准教授・博士 (工学) (2016 年 8 月 20 日逝去)

** 北海道大学大学院工学研究院空間性能システム部門 教授・工博

*** 北海道大学大学院工学研究院空間性能システム部門 助教・博士 (工学)
}

Assoc. Prof., Division of Human Environmental Systems, Faculty of Engineering, Hokkaido Univ., Dr. Eng.

Prof., Division of Human Environmental Systems, Faculty of Engineering, Hokkaido Univ., Dr. Eng. Assist. Prof., Division of Human Environmental Systems, Faculty of Engineering, Hokkaido Univ., Dr. Eng. 
性に違いがあると考えられる。ここでは, 上塗材の劣化は表面から 開始されるとともに, 耐候性は素地, 下塗, 既存塗膜によらず同程 度 5)であったことや, 経験的に樹脂系で耐候性の大小が評価されて きたことから，仕上塗材・塗料は樹脂系毎に同様に扱えると仮定し て, 整理を行うこととした。分類については, 多くのデータが報告 されている, アクリル樹脂系, ウレタン樹脂系, シリコーン樹脂 (ア クリルシリコン樹脂）系, ふっ素系樹脂系の 4 種類を主な対象とし

\section{表 1 実験の概要}

\begin{tabular}{|c|c|c|c|c|}
\hline 仕上材料名 & $\begin{array}{l}\text { 本論文で } \\
\text { 呼称 }\end{array}$ & $\begin{array}{l}\text { 上塗材 (TP) } \\
\text { の揮発成分 }\end{array}$ & 促進耐候性試験 ${ }^{8}$ & 屋外暴露試験 \\
\hline $\begin{array}{l}\text { 反応硬化形合成樹脂エマルション系 } \\
\text { 複層桬材 (TP：ウタン) }\end{array}$ & 複層 RE-U & 溶剽系 & \multirow{4}{*}{ 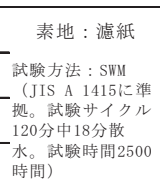 } & \multirow{4}{*}{ 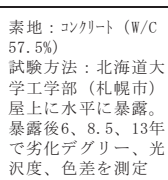 } \\
\hline $\begin{array}{l}\text { 反応硬化形合成樹脂エマルション系 } \\
\text { 複層塗材（TP：アリル) }\end{array}$ & 複層RE-A & 水系 & & \\
\hline シリコーン系塗料 & アクリルシリンン & 溶剤系 & & \\
\hline ふっ素系塗料 & ふっ素 & 溶剂系 & & \\
\hline
\end{tabular}

た。なお，シリコーン樹脂系は，一般にアクリルシリコン樹脂系と 呼称されているが, 本論文では, 本来の樹脂の名称を考慮し, シリ コーン樹脂系と呼称することとする。

\section{2 既報で提案した光沢保持率低下の予測式}

既報 5)において, 光沢保持率低下の予測式として, 式(1)を提案し ている。

$$
X=100 \times \frac{G_{l+h}}{G_{0}}=\frac{100}{\exp \left(A \exp \left(-\frac{B_{h}}{T}\right) \mathrm{t}+D \exp \left(-\frac{B_{l h}}{T}\right)(I t)^{a}\right)}
$$

ここで, $X$ : 光沢保持率 $(\%), G_{0}$ : 光沢度の初期值,

$G_{l+h}$ : 劣化後の光沢度, $T$ :材料温度 (絶対温度 $\left.(\mathrm{K})\right), t$ : 時間, $I$ : 単位時間における紫外線の強さ, $A, B_{h}, D, B_{l h}, a$ : 定数 既報 5)では, 総紫外線量(lt)a の指数 $\mathrm{a}$ は 1 と仮定し, 材料温度 $\mathrm{T}$ を相当環境温度 26) として, 式(2)を簡便な予測式として提案している。

表 2 光沢保持率のデータを収集した文献の概要

\begin{tabular}{|c|c|c|c|c|c|c|c|c|c|c|c|c|c|c|}
\hline \multirow[b]{2}{*}{ 文献 } & \multirow[b]{2}{*}{ 種類 } & \multicolumn{4}{|c|}{ 樹脂種類"11 } & \multicolumn{3}{|c|}{ 促進耐候性試験 } & \multicolumn{6}{|c|}{$\begin{array}{l}\text { 屋外暴露試験 } \\
\end{array}$} \\
\hline & & A & $\mathrm{U}$ & S & 他 & $\begin{array}{c}\text { 仕上塗材種類／主材 } \\
\text { (JIS A 6909等) }\end{array}$ & 試験方法 & 素地 & $\begin{array}{l}\text { デー } \\
\text { 夕数 }\end{array}$ & 暴露箇所（地点） & 素地 & 方位 & $\begin{array}{l}\text { 暴露 } \\
\text { 期間 } \\
\end{array}$ & $\begin{array}{l}\text { デー } \\
\text { 夕数 }\end{array}$ \\
\hline 1), 9) & 塗料 ${ }^{22}$ & $\bullet$ & - & $\bullet$ & - & - & $\begin{array}{l}\text { SWM（JIS D 0205, 6000時 } \\
\text { 間）, キセノンランプ法 } \\
\text { (JIS D 0205, 8000時間) 他 }\end{array}$ & $\begin{array}{c}\text { スレート } \\
\text { 板 }\end{array}$ & $\begin{array}{l}11 \\
11\end{array}$ & $\begin{array}{l}\text { 6箇所 (つくば市, 青梅 } \\
\text { 市, 豊川市, 高槻市, 大 } \\
\text { 阪市, 系満市) }\end{array}$ & $\begin{array}{c}\text { スレート } \\
\text { 板 }\end{array}$ & 南面垂直 & 10年 & 36 \\
\hline 10) & 塗料 & $\stackrel{0}{0}$ & $\stackrel{0}{0}$ & $\begin{array}{l}0 \\
0\end{array}$ & 0 & - & $\begin{array}{l}\text { SWM（JIS K } 5400 \text { 9.8.1準 } \\
\text { 拠，6000時間 }) * 8\end{array}$ & $\begin{array}{c}\text { スレート } \\
\text { 板 } \\
\end{array}$ & 5 & $\begin{array}{c}\text { 3箇所（つくば市，札幌 } \\
\text { 市，系満市) }{ }^{* 8}\end{array}$ & $\begin{array}{l}\text { スレート } \\
\text { 板/鋼板 }\end{array}$ & 南面 $30^{\circ}$ & 5年 & 5 \\
\hline $\begin{array}{l}\text { 8) } \\
\text { 本実 } \\
\text { 験 }\end{array}$ & $\begin{array}{l}\text { 仕上塗材, } \\
\text { 塗料 }\end{array}$ & $\diamond$ & $\bullet$ & - & e & $\begin{array}{l}\text { 薄塗材 } \mathrm{E} \\
\text { 厚塗材 } \mathrm{E} \\
\text { 複層塗材 } \mathrm{RE}\end{array}$ & $\begin{array}{l}\text { SWM（JIS A 1415，2500時 } \\
\text { 間） }\end{array}$ & 濾紙 & 4 & 1箇所（札幌市） & $\begin{array}{l}\text { コンク } \\
\text { リート }\end{array}$ & 水平 & 13 年 & 4 \\
\hline 11) & 塗料 & & & & $\bigcirc^{* 4}$ & - & $\begin{array}{l}\text { SWM（JIS K } 54009.8 .1 \text { 準 } \\
\text { 拠，2000時間） }\end{array}$ & 不明 & 2 & 1箇所（系満市） & 不明 & 南面 $23^{\circ}$ & 8年 & 2 \\
\hline $\begin{array}{l}\text { 12), } \\
\text { 13) }\end{array}$ & 塗料 & & & 0 & $\begin{array}{cc}\bigcirc & \bigcirc^{* 3} \\
0 & \bigcirc \\
\end{array}$ & - & $\begin{array}{l}\text { キセノンランプ法 (JIS K } \\
5600-7-7,8000 \text { 時間) }\end{array}$ & $\begin{array}{l}\text { 纎維強化 } \\
\text { セメント } \\
\text { 板 } \\
\end{array}$ & 5 & $\begin{array}{l}3 \text { 箇所 }(\text { 札幌市, つくば } \\
\text { 市, 宮古島) }{ }^{* 9}\end{array}$ & $\begin{array}{l}\text { 繊維強化 } \\
\text { セメント } \\
\text { 板 }\end{array}$ & $\begin{array}{l}\text { 南面 } 30^{\circ}(\text { (宮 } \\
\left.\text { 古島は } 20^{\circ}\right)\end{array}$ & 7年 & 10 \\
\hline 5) & 仕上塗材 & $\bullet$ & $\diamond$ & $\diamond$ & & $\begin{array}{l}\text { 薄塗材 } \mathrm{E} \\
\text { 複層塗材 } \mathrm{E} \\
\text { 防水形複層叙材 } \mathrm{E} \\
\text { 防水形薄塗 } \mathrm{E}\end{array}$ & - & - & - & $\begin{array}{l}\text { 4箇所 (石狩, つくば, } \\
\text { 東京, 沖永良部) }\end{array}$ & $\begin{array}{l}\text { コンク } \\
\text { リート }\end{array}$ & $\begin{array}{l}\text { 東・西・南・ } \\
\text { 北面垂直 }\end{array}$ & $\begin{array}{l}10.5 \\
\text { 年 }\end{array}$ & 40 \\
\hline 14) & $\begin{array}{l}\text { 塗料 (一部 } \\
\text { 仕上塗材) }\end{array}$ & $\begin{array}{l}\bullet \\
\ominus \\
\diamond \\
\end{array}$ & - & & $\bullet^{* 6}$ & (n) & - & - & - & $\begin{array}{l}\text { 6箇所 (恵庭市, つくば } \\
\text { 市, 東京都, 平塚市, 尼 } \\
\text { 崎市, 沖永良部) }\end{array}$ & 鉄板 & 南・北面垂直 & 4年 & 36 \\
\hline 15) & 仕上塗材 & & $\bullet$ & & & $\begin{array}{l}\text { アクリルゴム系 } \\
\text { ウレタンゴム系 } \\
\text { ウレタン樹脂十七メ } \\
\text { ウト系 }\end{array}$ & - & - & - & 1箇所（佐賀県玄海町） & $\begin{array}{l}\text { コンク } \\
\text { リート }\end{array}$ & $\begin{array}{l}\text { 東・西・南・ } \\
\text { 北面垂直 }\end{array}$ & 20 年 & 3 \\
\hline 16) & 仕上塗材 & $\bullet$ & 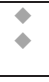 & & 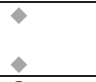 & $\begin{array}{l}\text { アクリルゴム系 } \\
\text { アクリルゴム系 } \\
\text { ウレタンゴム系 } \\
\end{array}$ & - & - & - & 1箇所（千葉市） & $\begin{array}{l}\text { フレキシ } \\
\text { ブル板 }\end{array}$ & 南面 $45^{\circ}$ & 3年 & 5 \\
\hline 17) & 塗料 & & - & $\bullet$ & $?$ & - & - & - & - & $\begin{array}{c}\text { 2箇所（沖縄県西原町， } \\
\text { 宜野湾市） }\end{array}$ & アルミ板 & 南面 $30^{\circ}$ & 4年 & 6 \\
\hline 18) & 仕上塗材 & $\bullet$ & 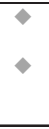 & & $\Leftrightarrow$ & $\begin{array}{l}\text { アクリルゴム系 } \\
\text { エポキシ樹脂系 } \\
\text { エポキシ樹脂系 } \\
\text { エポキシ樹脂系 } \\
\text { アクリルゴム系 }\end{array}$ & - & - & - & $\begin{array}{c}\text { 2箇所（東京都，柏崎 } \\
\text { 市) }\end{array}$ & $\begin{array}{l}\text { スレート } \\
\text { 板 }\end{array}$ & 南面 $45^{\circ}$ & $\begin{array}{l}10.9 \\
\text { 年 }\end{array}$ & 5 \\
\hline 19) & 塗料 & & & & $\bigcirc^{* 5}$ & - & $\begin{array}{l}\text { SWM（JIS H 8602，10000時 } \\
\text { 間）他 }\end{array}$ & アルミ板 & 3 & 1箇所（印西市） & アルミ板 & 南面 $30^{\circ}$ & 9年 & 3 \\
\hline 21) & 塗料 & 0 & $\stackrel{?}{\circ}$ & $\bullet$ & $\bullet \boldsymbol{\bullet}^{* 7}$ & - & $\begin{array}{l}\text { SWM（JIS D 0205，3500時 } \\
\text { 間） }\end{array}$ & 不明 & 9 & - & - & - & - & - \\
\hline 22) & 塗料 & 0 & 8 & 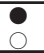 & 0 & - & $\begin{array}{l}\text { SWM（JIS A 1415，5000時 } \\
\text { 間) }\end{array}$ & $\begin{array}{l}\text { フレキシ } \\
\text { ブル板 }\end{array}$ & 42 & - & - & - & - & - \\
\hline 23) & 塗料 & & - & ? & $\bullet^{* 5}$ & - & $\begin{array}{l}\text { SWM（JIS K } 5400 \quad 9.8 .1 \text { 準 } \\
\text { 拠，2000時間） }\end{array}$ & $\begin{array}{c}\text { スレート } \\
\text { 板 } \\
\end{array}$ & 7 & - & - & - & - & - \\
\hline 24) & 塗料 & & & & $0^{* 5}$ & - & $\begin{array}{l}\text { SWM (JIS H 8602, 7000時 } \\
\text { 間) }\end{array}$ & アルミ板 & 12 & - & - & - & - & - \\
\hline 25) & 塗料 & & & & $0^{* 5}$ & - & $\begin{array}{l}\text { SWM（JIS K } 54009.8 .1 \text { 準 } \\
\text { 拠, } 4000 \text { 時閒) }\end{array}$ & アルミ板 & 10 & - & - & - & - & - \\
\hline $\begin{array}{ll}* 1 & \mathrm{~A}: \\
& \bigcirc \\
* 2 & \jmath \\
* 6 & \jmath\end{array}$ & $\begin{array}{l}\text { :アクリル樹脂 } \\
\text { : 叙料, ○: } \\
\text { クリル樹脂, } \\
\text { ルキド樹脂系 }\end{array}$ & 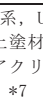 & $\begin{array}{l}: \text { ウレ } \\
\text { として } \\
\text { ルシリ } \\
\text { 無機柔 }\end{array}$ & $\begin{array}{l}\text { コン } \\
\text { コ梌料 }\end{array}$ & 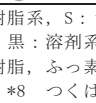 & 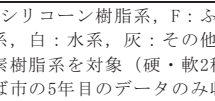 & 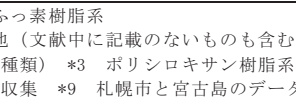 & $\begin{array}{l}\text { *4 ポリウ } \\
\text { 少のみ収集 }\end{array}$ & フレタン & ン樹脂系 $* 5$ ポリエステル樹 & 脂系 & & & \\
\hline
\end{tabular}




$$
\begin{aligned}
& X=\frac{100}{\exp (\beta t)} \\
& \text { ここで, } \beta=A \exp \left(-\frac{B_{h}}{T}\right)+D \exp \left(-\frac{B_{l h}}{T}\right) \times I
\end{aligned}
$$

できるだけ簡便な式の方が, 実用性は高いと考えられることから， 以下, 式(2)について屋外暴露試験および文献調查から得られた光沢 保持率のデータに基づきその適用性の検討を行う。

\section{3. 実験結果および文献調査結果および考察}

\section{1 光沢保持率低下の提案式の屋外暴露試験結果および促進耐候} 性試験結果への適用性の検討

（1）屋外暴露試験結果一の適用

屋外暴露試験の結果を図 1 に示す。図中の点線は式(2)に基づき最 小自乗法により求めた係数 $\beta$ を用いた光沢保持率の予測例（図 2 ,

図 4 も同じ表現) であり, 光沢保持率低下の進行を表現できている と考えられる。既往研究のデータに対し同様に光沢保持率を予測し た例を図 2 に示す。実測值を表現できているものと, 実測值と予測 值が乘離しているものがみられた。文献調查から得られた屋外暴露
試験と本実験の全 155 データを対象として, 実測值と式(2)による予 測值の重相関係数の範囲を図 3 に示す。147（全体の約 95\%）のデ 一タが重相関係数 0.80 以上を示した。樹脂系毎の重相関係数の平均 值を図 3 中に示しているが，今回の調査範囲ではふっ素樹脂系は低 い結果となった。図 2 中央に示寸通り，光沢保持率低下が小さいも のが多かったことが要因と考えられる。一部, 図 2 右に示すように, 低下した光沢保持率が再び上昇している場合も低い重相関係数を示 し, 一様な低下ではない場合は, 式(2)の適用は困難と考えられる。 （2）促進耐候性試験結果一の適用

SWM 試験の既往研究のデータによって算出した例を図 4 に示寸。 屋外暴露試験と同様に，実測值を表現できているものと，実測值と 予測值が乘離しているものがみられた。SWM 試験の 111 データを 対象として, 予測值と実測值の重相関係数の範囲を図 5 に示寸。 SWM 試験の結果は屋外暴露試験よりも重相関係数が低い傾向とな ったが，68（全体の約 61\%）のデータが重相関係数 0.80 以上を示 した。SWM 試験の結果は屋外暴露試験よりも測定点数が多いこと から，測定誤差の影響で重相関係数が低くなったことが一因と考え られる。図 5 中に各樹脂系の重相関係数の平均值を示寸。耐候性が 高いと考えられるものほど重相関係数は低下し, 特に屋外暴露試験 と同様，ふっ素樹脂系の重相関係数は低い結果となった。光沢保持

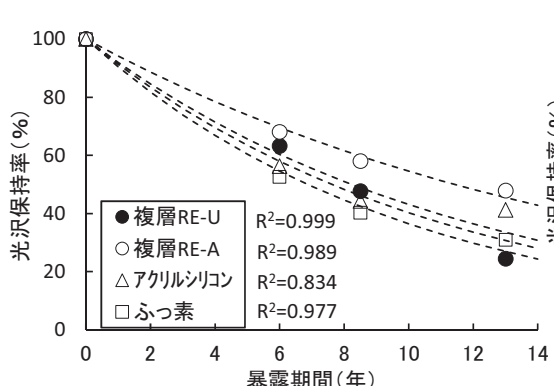

図 1 屋外暴露試験の光沢保持率低下

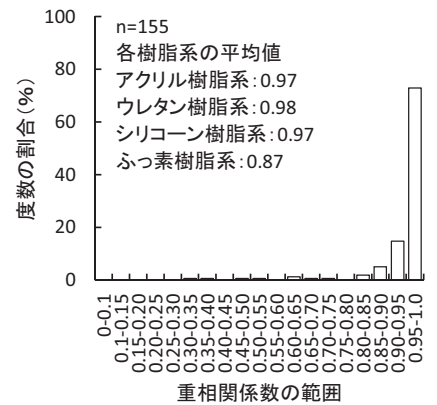

図 3 本実験および既往研究の屋外暴露試験結

果と式(2)による予測値との重相関係数の範囲

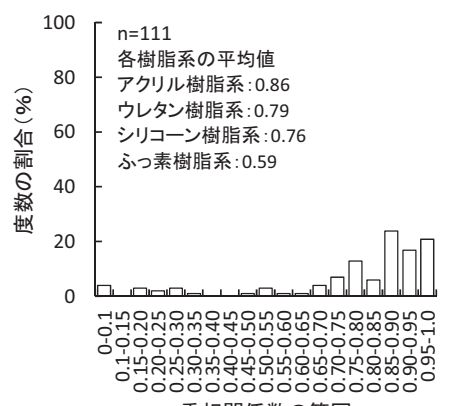

図 5 既往研重梘開係数の範围 による予測値との重相関係数の範囲
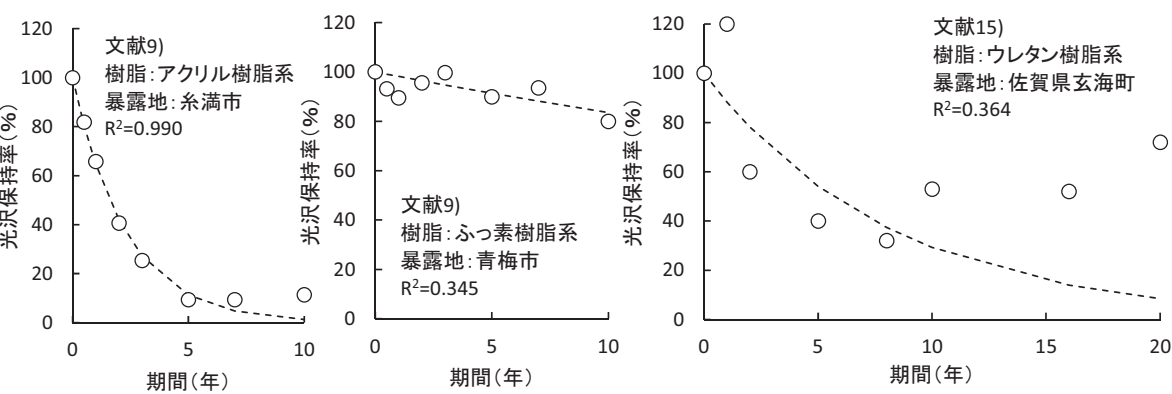

図 2 既往研究における屋外暴露試験結果と式(2)との対応の例
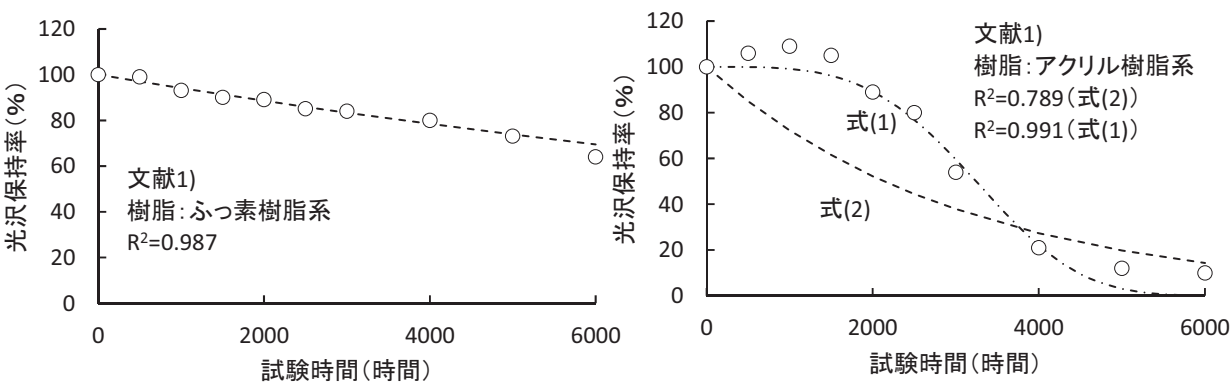

図 4 既往研究における SWM 試験結果と式(2)との対応の例

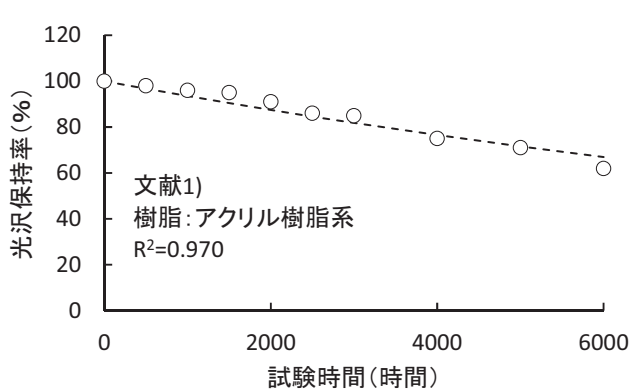

図 6 既往研究におけるキセノン法試験結 果と式(2)との対応の例

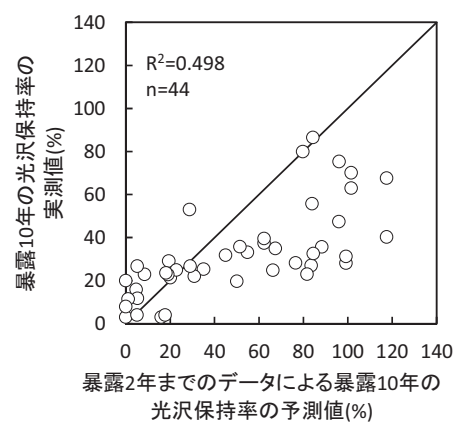

図 7 屋外暴露 2 年目までのデータによる 屋外暴露 10 年の予測値と実測値の関係 
率が低下しない場合, 式(2)で進行を表すことは困難であると考えら れる。また，図 4 右に示すように初期では光沢保持率が低下せず, 途中から低下寸る場合が SWM 試験ではより多くみられた。式(2) ではなく式(1)の各係数を最小自乗法により求めた結果（一点鎖線） を図 4 右中に示寸。途中から光沢保持率が低下寸る場合, 式(1)によ る方が精度よく表すことができるといえる。この原因として, 総紫 外線量 $(I t) a$ の指数 $a$ を 1 と仮定していたが, この仮定が適当でなく, 既往研究 4)で言及されている通り, 正確に予測する場合は材料毎に 評価する必要があると考えられる。しかし，SWM 試験でも 6 割以 上, 屋外暴露試験では 9 割以上が高い重相関係数を示していること から, 実用的には式(2)によって光沢保持率低下の進行を表すことが できると思われる。ここで, 図 6 に既往研究におけるキセノンラン プ法の試験結果の例を示す。試験結果の収集数が少なかったため, 屋外暴露試験, SWM 試験のような分析をしていないが, キセノン ランプ法の光沢保持率低下も式(2)で表現可能と考えられる。

(3) 短期の屋外暴露結果による長期の屋外暴露結果の予測

10 年以上の屋外暴露試験（2 年のデータがあるもの） 9$), 15), 18)$ に る光沢保持率の低下が屋外暴露 2 年までの短期間の結果で予測でき るかについて検討を行った。屋外暴露試験 2 年までの結果から係数 $\beta$ を最小自乗法により算出し, その $\beta$ を用いて屋外暴露 10 年時の 光沢保持率を予測し, その結果と実測值を比較した。結果を図 7 に 示す。両者の重相関係数は 0.49 程度と低い結果となった。これは, 初期は光沢保持率低下が生じていない場合が見られており, 短期間 の屋外暴露結果から評価した場合, 長期的な屋外暴露試験結果は危 険側の評価になる可能性があるといえる。

\section{2 暴露地域・樹脂種類による係数 $\beta$ のばらつき}

係数 $\beta$ は, 屋外暴露環境条件と仕上塗材・塗料種類の両方の影響 を受けるが, 両者の影響の大きさを検討する上で, 屋外暴露環境に よる光沢度低下の差を検討する必要がある。同仕様の試験体を複数 の地点で屋外暴露試験を行った文献 5),9),14)を対象として, 地域毎の 仕上塗材・塗料種類の差に対する式(2)の係数 $\beta$ の変動係数と仕上塗 材 ・塗料種類毎の地域の差に対する変動係数の算出を行った。結果 を表 3 に示す。ここで, 変動係数が大きいということは, 個々の試 験体の光沢保持率の差が大きいということであり, その要因の影響 が大きいと考えられる。表から, いずれの文献においても, 一部突 出して大きい変動係数を除くと, 地域毎の仕上塗材 - 塗料種類の差 による変動係数よりも仕上塗材・塗料種類毎の地域の差に対する変 動係数が小さい結果となっている。このことから, 屋外暴露による 光沢保持率の低下には, 仕上塗材 - 塗料種類の影響が大きく, 仕上 塗材・塗料種類のポテンシャルの耐候性の影響が大きいといえる。 なお，突出して大きい変動係数を示寸原因は明確ではないが，污れ の付着などの影響などが考えられる。また, 仕上塗材・塗料種類毎 の地域の差に対する変動係数の平均值は概ね $30 \%$ 程度となってい る。各文献の屋外暴露地には北海道から沖縄まで含まれていること を考えると, 日本の一般的な地域間における熱・光による劣化進行 を表す係数 $\beta$ の変動は, 変動係数で約 $30 \%$ であり, 比較的小さいと いえる。ただし, 海岸近くなど, 特別な環境では異なることも考え られ, 今後の検討課題と考えられる。

\section{3 促進耐候性試験と屋外暴露試験の関係の検討}

耐久性総プロで示された仕上塗材・塗料の推定耐用年数は, 式(3)
によることとされている27)

$Y=Y_{S} \times O \times D \times B \times C \times M$

ここに， $Y_{S}$ : 標準耐用年数 (年), $O$ : 材料による係数, $D$ : 地域 環境による係数, $B$ : 部位による係数, $C$ 施工水準による係数, $M$ : 維持保全による係数

促進耐候性試験と屋外暴露試験との関係において, 暴露年数 1 年 相当促進時間を求めると, 試験方法, 樹脂種類によって異なること が指摘されている1)。このため，式(3)において地域による条件は係 数 $D$ で考慮されるが, 実環境での耐用年数を知りたい場合, 材料 毎・地域毎に屋外暴露試験を実施する必要がある。

ここで, 前節で示した通り, 光沢保持率の低下は, 暴露地の影響 よりも仕上塗材・塗料種類の影響が大きいことが示唆された。つま り，塗膜がもつポテンシャルの耐候性の影響が地域環境条件の影響 よりも大きいと考えることができる。ここで，促進耐候性試験で求 めた $\beta$ から, 屋外暴露試験での $\beta$ の平均值が一意に決まると仮定す る。この屋外暴露試験での $\beta$ の平均值が, 標準的な耐候性を表すと 考えると, 部位・地域条件による違いは，この標準的な $\beta$ に対する

\begin{tabular}{|c|c|c|c|c|c|c|}
\hline 文献 & $\begin{array}{l}\text { 塗材 } \\
\text { 類 }\end{array}$ & $\begin{array}{l}\text { 暴露 } \\
\text { 所所 }\end{array}$ & $\begin{array}{c}\text { 地域毎の仕上塗 } \\
\text { 材・塗料種類の差 } \\
\text { に対する変動倸数 } \\
(\%) \\
(\%)\end{array}$ & $\begin{array}{c}\text { 平均値 } \\
(\%)\end{array}$ & $\begin{array}{l}\text { 仕上塗材・塗料種類 } \\
\text { 毎の地域の差に対す } \\
\text { る変動係数 }(\%)^{* 1}\end{array}$ & $\begin{array}{c}\text { 平均值 } \\
(\%)\end{array}$ \\
\hline 5) & & 9 & $28.1 \sim 56.9$ & 40.8 & $10.3 \sim 62.8 \quad(25.9)$ & $21.2^{* 2}$ \\
\hline 9) & & 6 & $44.3 \sim 85.5$ & 68.0 & $12.4 \sim 54.9$ & 30.1 \\
\hline 14) & 7 & 6 & $31.6 \sim 79.1$ & 56.6 & $17.1 \sim 303.1 \quad(42.2)$ & $30.5^{* 2}$ \\
\hline
\end{tabular}

○:アクリル·アクリルウレタン $\triangle$ :アクリルシリコン $\square:$ フッ素

白: 文献1),9) 黒: 文献10) 灰色: 文献8), 本実験

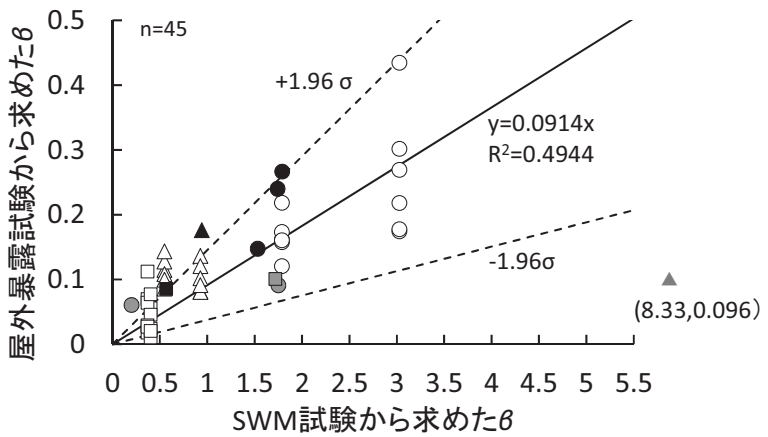

図 8 SWM 試験から求めた $\beta$ と屋外暴露試験から求めた $\beta$ の関係

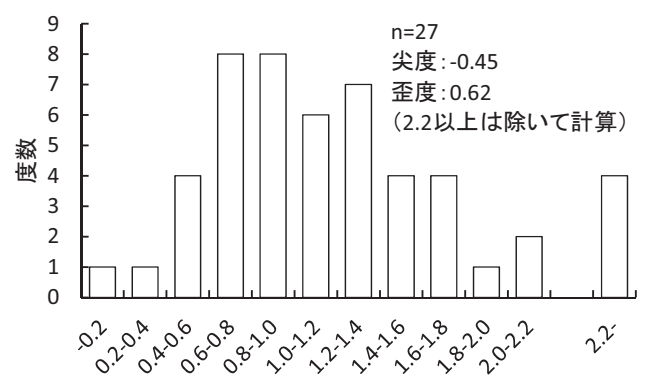

図 9 平均を 1 とした時の屋外暴露試験の $\beta$ のばらつき 
ばらつきとして表現できると考えられる。

(1) SWM 試験と屋外暴露試験の関係

SWM 試験と屋外暴露試験を行っているデータを対象として, SWM 試験 1), 8),10) から求めた $\beta$ と屋外暴露試験 9),10)おび゙本実験結 果から求めた $\beta$ の関係を図 8 に示す。なお, SWM 試験は芳香族に 属寸る樹脂系は屋外暴露試験と相関が低いことが指摘されているこ とから ${ }^{2)}$, 脂肪族の樹脂系の夕を対象とした。この時の平均值を 1 として平均值に対する比のばらつきを図 9 に示す。データ数は少な いが, 尖度, 歪度は 0 に近いことから, 正規分布に従うと仮定した。 変動係数を前述の $30 \%$ と仮定した場合の危険率 $5 \%$ のライン（士 1.96 o) を図 8 中に示す。シリコーン樹脂系, ふっ素樹脂系など耐 候性が高いものは, 危険率 $5 \%$ $\%$ ラインを超えるものがみられるが, 他は概ねこのラインの中にあることがわかる。屋外暴露の $\beta$ は $\mathrm{SWM}$ 試験の $\beta$ の約 0.091 倍, 促進倍率（促進耐候性試験の試験時 間が屋外暴露試験の何年に相当するかの倍率) にして約 10.9 倍とな った。シリコーン樹脂系, ふっ素樹脂系など而候性が高い塗膜が $5 \%$ のラインを超えた理由は, 明確ではないが, 屋外暴露時の污れ等の 影響とともに，促進耐候性試験でのばらつきが考えられる。促進耐 候性試験のばらつきについて, 複数メーカーの同じ樹脂系で実施さ れた SWM 試験 22 ) における各樹脂系の係数 $\beta$ の変動係数を表 4 に示 す。同じ樹脂系でもばらつきが大きく, 特に耐候性が高いものは, ばらつきが大きいことがわかる。このばらつきは, 樹脂の化学組成 によるもの, 試験条件によるものが含まれていると考えられ, 化学 組成による影響が大きいと考えられる。試験条件のばらつきについ てはデータが少なく明確ではないが, 文献 22) より比較的化学組成が 近い条件と考えられるアクリル樹脂系の変動係数が 0.30 であり, 試 験条件によるばらつきに近いものと推測される。促進耐候性試験結 果はこの程度のばらつきを考慮する必要があると考えられる。

(2) キセノンランプ法試験と屋外暴露試験の関係

同様に, キセノンランプ法試験での結果 1),12) と屋外暴露試験 9),13) での結果を図 10 に示す。キセノンランプ法でも SWM 試験と同様 の傾向がみられた。文献 ${ }^{13)}$ の宮古島の結果を除いて求めた屋外暴露 の $\beta$ は SWM 試験の $\beta$ の約 0.11, 促進倍率にして約 9 倍となった。 ここで, JIS A 6909:200328)からは, 促進耐候性試験としてキセノン ランプ法が採用されており, SWM 試験から試験時間が改められて いる。SWM に対してキセノン法は $1.2 \sim 1.25$ 倍の試験時間となっ ているが，今回の結果でも SWM 試験とキセノンランプ法の試験時 間の比率は約 1.2 倍となり, 概ね JIS で示された比率と一致する結 果となった。文献 ${ }^{13)}$ の宮古島の結果は, 屋外暴露の $\beta$ の值が著しく 危険率 $5 \%$ のラインを大幅に上回る結果となった。この原因は明ら かではないが，海塩粒子の影響などを考慮する必要があると考えら れる。

（3）促進耐候性試験結果による光沢保持率低下の予測

以上の結果より，促進耐候性試験をその塗膜のポテンシャルの耐 候性と考えると, 式(4)，(5)に示寸通り, 促進耐候性試験より屋外暴 露試験の $\beta$ を推定し, これにばらつきを考慮することで, 光沢保持 率低下の予測が可能となると考えられる。

$$
X=\frac{100}{\exp \left\{\left(\beta_{e} \pm c \sigma\right) t\right\}}
$$

表 4 既往研究 ${ }^{22)}$ における各樹脂系の SWM 試験から求 めた $\beta$ の変動係数

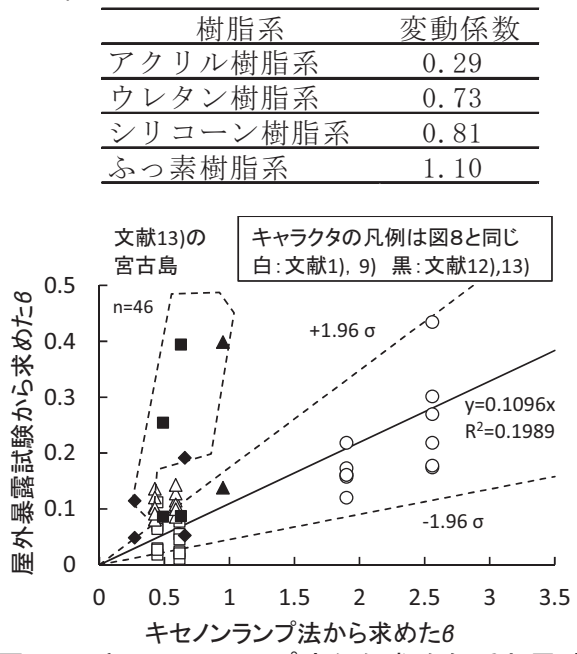

図 10 キセノンランプ法から求めた $\beta$ と屋外暴露試験か ら求めた $\beta$ の関係

\begin{tabular}{|c|c|c|c|c|c|c|c|}
\hline & 樹脂系 & $\begin{array}{l}\text { データ } \\
\text { 数 }\end{array}$ & $\begin{array}{l}\beta \sigma \\
\text { 平均值 }\end{array}$ & $\begin{array}{l}\text { 変動倸 } \\
\text { 数 }\end{array}$ & $\begin{array}{l}\text { 推定耐 } \\
\text { 用年数 } \\
\text { (年) }\end{array}$ & $\begin{array}{l}\text { 文献 }^{29)} \text { で提 } \\
\text { 案された仮 } \\
\operatorname{RSLC~(19)~}\end{array}$ & $\begin{array}{l}\text { 仮RSLCか } \\
\text { ら求めた } \\
\beta\end{array}$ \\
\hline \multirow{4}{*}{ 溶 } & アクリル樹脂系 & 41 & 0.30 & 0.57 & 4 & 4 & 0.30 \\
\hline & ウレタン樹脂系 & 25 & 0.17 & 0.49 & 7 & 7 & 0.17 \\
\hline & シリコーン樹脂系 & 14 & 0.11 & 0.25 & 11 & 10 & 0.12 \\
\hline & ふっ素樹脂系 & 30 & 0.06 & 1. 49 & 20 & 13 & 0.09 \\
\hline \multirow{4}{*}{ 水 } & アクリル樹脂系 & 12 & 0.27 & 0.38 & 4 & 5 & 0.24 \\
\hline & ウレタン樹脂系 & 5 & 0.09 & 0.08 & 13 & 7 & 0.17 \\
\hline & シリコーン樹脂系 & 6 & 0.14 & 0.74 & 9 & 9 & 0.13 \\
\hline & ふっ素樹脂系 & 2 & 0.25 & 0.87 & 5 & 11 & 0.11 \\
\hline
\end{tabular}

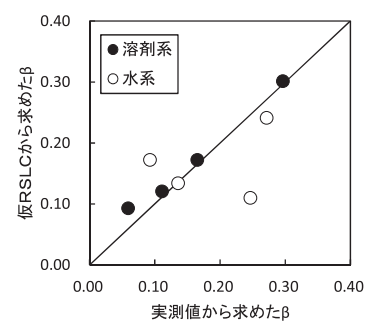

図 11 実測値と仮 RSLCから 求めた $\beta$ 関係

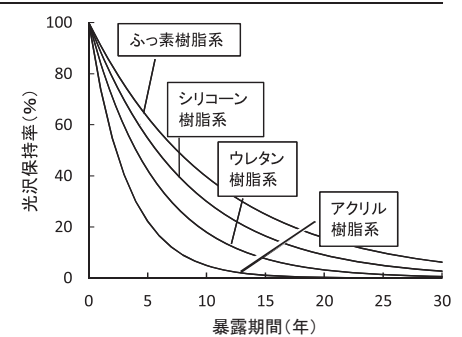

図 12 仮 RSLC から求めた各樹 脂系 (溶剂系) の光沢保持率

$$
\beta_{e}=m \times \beta_{a}
$$

ここに, $\beta_{e}:$ 屋外暴露試験による $\beta$ の平均值,

$c$ : 危険率に応じた係数 $(95 \%$ の場合 1.96$), \sigma: \beta$ の標準偏差, $m:$ 促進倍率（SWM 試験：0.09, キセノンランプ法 : 0.11), $\beta_{a}:$ 促進耐候性試験による $\beta$

式(3)で示された地域, 部位, 施工水準, 維持保全状況を, ばらつ きとして表現することで，塗膜の耐久設計ができると考えられる。 これらの要因によるばらつきをどのように設定するかは，明らかで はなく, 今後実建物データの蓄積により検討が必要である。

\section{4 樹脂系と耐候形 1 ～種の位置づけの検討}

各樹脂系の耐用年数を検討寸るため, 文献調查結果を樹脂系で分 類し，整理を行った。整理にあたり，溶剤系・水系等の別は文献の 記載の通りに分類した。なお，溶剤系・水系等の別について記載の ない文献は, 試験体作製時期から溶剂系と推定した。結果を表 5 に 示す。ばらつきがみられるものの，樹脂系毎に近い值となる傾向を 示した。ここで添田ら 29)は，光沢保持率が 30\%となる時点を美観 上の寿命（耐用年数）として，仮 RSLC（Reference Service Life of 


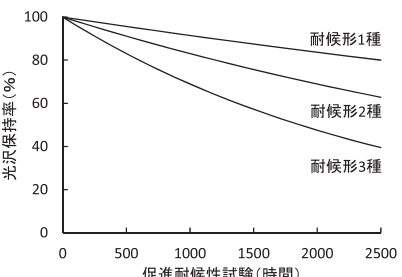

図 13 促進耐候性試験 (キセノ ン法)による各耐候形の位置づけ

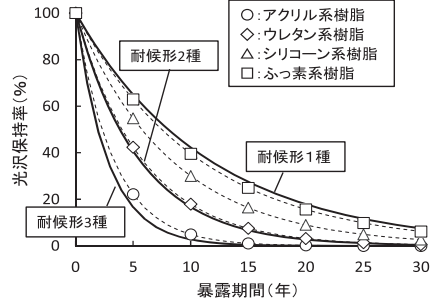

図 14 推定した屋外暴 露環境における各耐候形 の位置づけ
Components。仕上塗材の上塗材の值）を提案している。実測值か ら求めた $\beta$ と仮 RSLC から求めた $\beta$ の関係を図 11 に示す。データ 数の少ない水系では一致しないものもあるが，概ね一致する傾向を 示した。この仮 RSLC が美観の観点からみた各樹脂系の標準的な耐 用年数であると仮定すると, この係数 $\beta$ は各樹脂系の標準的な光沢 保持率低下の進行を表すと考えられる。この係数 $\beta$ を用いた各樹脂 系 (溶剤系) の光沢保持率低下を図 12 に示す。

JIS A 6909 に規定された耐候形 1〜3 種は, それぞれキセノンラ ンプ法試験において 600 時間 (3 種)， 1200 時間 (2 種)，2500 時 間 (1 種) の間, 光沢保持率 $80 \%$ 以上であることが求められている。 光沢保持率低下が式(2)に従うとすると, その進行は図 13 のように なる。ここで, 図 10 に示した関係式より屋外暴露試験の結果を推 定すると図 14 のようになる。図 14 中に図 12 に示した各樹脂系の 光沢保持率低下の進行を併せて示す。アクリル樹脂系は耐候形 3 種, ウレタン樹脂系は耐候形 2 種, ふっ素樹脂系は耐候形 1 種にほぼ相 当する結果となり，経験的に知られている耐候形の種別に相当する 樹脂系種類と概ね一致する結果を得た。以上, 各樹脂系の標準的な 光沢保持率低下と JIS A 6909 に規定された耐候形の位置づけを示 した。この結果を基にメーカーのカタログに示された耐候性から耐 久設計を行うことができると考えられる。しかし, 現在はここに示 した以外の塗膜も多くあり, 光沢保持率の評価が難しい艶消し等も 増えてきていることから, 今後, これらの塗膜についても検討が必 要と考えられる。

\section{4.まとめ}

（1）既報で提案した光沢保持率低下の予測式は，屋外暴露試験，促進 耐候性試験ともに概ね実測值を表現できることを確認した。

(2)光沢保持率は，暴露地の影響よりも塗膜種類の影響が大きい。

(3)光沢保持率低下の進行を表す係数 $\beta$ の変動は, 一般的な地域の場 合，変動係数で約 $30 \%$ である。

(4)地域による差をばらつきと考え, 促進耐候性試験の結果から屋外 暴露試験の結果を予測する手法を提案した。

(5)各樹脂系の標準的な光沢保持率低下の進行を表す係数 $\beta$ の值を 示した。

\section{参考文献}

1) 竹内博幸, 矢野瑞穂, 和田高清: 外壁用塗料の耐候性能評価に関寸る研究, その 32 促進耐候性試験と屋外暴露試験による評価の比較, 日本建築学会 大会学術講演梗概集 A-1，pp. 985-986，1996.7

2) 飯田眞司他 2 名: 促進耐候性試験法, 塗料の研究第 145 号, pp. 22-37, 2006. 3 3) 近藤照夫，青柳久足，藤城春雄，小久保正美：建築外装用仕上げ塗料の而 久性能評価その 1 アクリル樹脂系塗料の実態調査, 日本建築学会大会
学術講演梗概集 A-1，pp. 523-524，1993.7

4) 小池迪夫, 田中享二：合成高分子防水層の耐候性，その 6 光熱劣化におけ る光と熱の定量的評価, 日本建築学会論文報告集第 289 号, pp. 1-10, 1980.3

5) 長谷川拓哉，朴宰弘，千歩修，濱崎仁：屋外暴露試験に基づく仕上塗材の 劣化と鉄筋コンクリート造躯体保護効果の経年変化, 日本建築学会構造系 論文集 N0.686, pp. 679-686，2013.4

6) 長谷川拓哉, 千歩修: 屋外暴露環境下における仕上塗材・塗料の光沢保持 率低下予測に関する検討, 2012 年大会学術講演会研究発表論文集, 2012.10

7)長谷川拓哉，千歩修，福山智子：文献調査に基づく建築用塗料・仕上塗材 の促進耐候性試験による劣化進行予測に関する検討, 2014 年大会学術講演 会研究発表論文集, 2014.10

8) 長谷川拓哉, 千歩修, 大久保孝昭, 古賀純子：建築仕上塗材の中性化抑制 効果に関する研究, 日本建築学会構造系論文集第 609 号, pp. 23-30, 2006. 11

9) 茂木正史他 6 名：外壁用塗料の耐候性能評価に関する研究 その 40 全国 6 ヶ所における屋外暴露 10 年までの光沢残存率, 日本建築学会大会学術講 演梗概集 A-1，pp. 207-208，2000.9

10) 栗原大典他 4 名：有機溶剤を低減した環境対応形塗料の屋外暴露 10 年後 の結果，日本建築学会大会学術講演梗概集 A-1，pp. 1101-1102，2006.9

11) 堀長生, 奥田章子他 3 名：塗装仕上げの耐久性向上技術に関する研究，日 本建築学会大会学術講演梗概集 A-1, pp. 1091-1092, 2014.9

12）今泉桂，本橋健司：ポリシロキサンを主成分とする塗料の性能評価，日 本建築学会大会学術講演梗概集 A-1, pp. 471-472, 2008.9

13）今泉桂，本橋健司：ポリシロキサンを主成分とする塗料の性能評価 そ の 5 屋外暴露 7 年後の而久性評価, 日本建築学会大会学術講演梗概集 A-1, pp. 1075-1076, 2014.9

14)平田信人，樫野紀元，冨板崇：各種環境下における建築用塗料の耐候性と 耐污染性の評価, 日本建築学会構造系論文集 No. 553, pp. 19-25, 2002.3

15)御手洗泰文他 4 名: 重要構造物マスコンクリートの管理 一保護塗装の効 果と耐久性に関する 20 年のモニタリング試験結果一, 日本建築学会技術報 告集第 13 巻第 26 号, pp. 389-394, 2007. 12

16) 平野竜行, 村上信直: 外装塗材の性能評価に関する研究，その 2 塗材表 面の劣化挙動について, 日本建築学会大会学術講演梗概集 A-1, pp. 43-44, 1989. 10

17) 犬飼宏，西尾竜生，大城武：沖縄における高性能仕上塗材の耐候性評価, 日本建築学会大会学術講演梗概集 A-1, pp. 1367-1368, 1995.8

18)佐々木正治他 3 名: 外壁仕上材の耐候性およびコンクリートの保護性に関 する 131 ケ月の屋外暴露試験結果, その 1 . 仕上塗材の耐候性, 日本建築学 会大会学術講演梗概集 A-1，pp. 479-480，1997.9

19) 後藤善光, 朝倉崇博, 大澤悟: 外装アルミ用塗料の耐久性に関する研究 そ の 17 高耐候性ポリエステル粉体塗料の屋外暴露 9 年目の評価, 日本建築 学会大会学術講演梗概集 A-1, pp. 1089-1090, 2014.9

20) 河野政典他 3 名: 仕上塗材の経年劣化を考慮した中性化抑制効果に関する 研究，日本建築学会構造系論文集第 584 号，pp. 15-21，2004. 10

21) 三浦勇雄, 矢野瑞穂 : 低污染性外装用塗料の而污染性能と而候性能評価に 関する研究 その 2 サンシャインウェザーメータによる耐候性能評価結 果, 日本建築学会大会学術講演梗概集 A-1, pp. 859-860, 1997.9

22)今泉桂, 本橋健司, 三浦正継：環境対応型塗料の耐候性能について, その 2 サンシャインウェザーメータによる評価, 日本建築学会大会学術講演梗 概集 A-1，pp. 617-618，1997.9

23) 伊藤孝男他 5 名 : 光触媒を利用した外装用塗料の耐候性評価, 日本建築学 会大会学術講演梗概集 A-1, pp. 1099-1100，2004.8

24) 朝倉崇博, 齋藤俊, 大澤悟 : 外装アルミ用塗料の耐久性に関する研究 そ の 11 各種粉体塗料の基本物性及び促進劣化試験, 日本建築学会大会学術 講演梗概集 A-1，pp. 987-988，2013.8

25) 奥田章子, 堀長生 : 金属下地塗装に関する研究 その 2 ふつ素樹脂粉体 塗装の耐候性評価，日本建築学会大会学術講演梗概集 A-1，pp. 995-996, 2013.8

26) 小池迪夫，田中享二：合成高分子防水層の耐候性，その 4 屋外暴露にお ける熱の影響の評価, 日本建築学会論文報告集第 263 号, pp. 11-118, 1978.1 27) 建設省: 建設省総合技術開発プロジェクト 建築物の耐久性向上技術の開 発 報告書, 1985

28) JIS A 6909 (建築用仕上塗材)，2003.3

29) 添田智美他 6 名 : 外装用塗料・仕上塗材の標準耐用年数に関寸る調査研究 その 6 美観上の塗装仕様別リファレンスサービスライフの設定, 日本建 築学会大会学術講演梗概集 A-1，pp. 1067-1068, 2009.8 


\title{
PROPOSAL ON WEATHERABILITY EVALUATION OF COATING MATERIALS BASED ON LITERATURE SURVEYS
}

\author{
Takuya HASEGAWA*, Osamu SENBU** and Tomoko FUKUYAMA*** \\ * Assoc. Prof., Division of Human Environmental Systems, Faculty of Engineering, Hokkaido Univ., Dr. Eng. \\ ** Prof., Division of Human Environmental Systems, Faculty of Engineering, Hokkaido Univ., Dr. Eng. \\ *** Assist. Prof., Division of Human Environmental Systems, Faculty of Engineering, Hokkaido Univ., Dr. Eng.
}

From the viewpoint of the durability of coating materials for buildings, the estimation of their weatherability is critical. JIS A 6909 has regulated the weatherability types for coating materials based on the accelerated weatherability tests. However, the relationship between the deterioration progress in coating materials under the accelerated weatherability test and that under the outdoor exposure test is not clear yet.

An outdoor exposure test on coating materials for 13 years in Sapporo, a literature survey on the results of the outdoor exposure tests and accelerated weatherability tests (using the sunshine and Xenon lamp weather meters) were carried out to elucidate the relationship. In a previous study, the authors proposed an equation for estimating the gloss retention decrease, which is an indicator of deterioration in coating materials. In this study, the applicability of the proposed equation to the experimental results of the outdoor exposure test and literature survey was investigated. The results showed a high correlation between the estimated results and the measured results for gloss retention though there are some exceptions.

To investigate the estimation method of the gloss retention after the long term exposure at the initial material age, we also compared the ten years gloss retention measured values to estimated values using two years values. The estimation of the long-term outdoor exposure results from the short-term results was difficult. The outdoor exposure test results from multiple regions showed that the weatherability was mainly affected by the coating material type.

A method for the estimation of the gloss retention decrease during the outdoor exposure test using the accelerated weatherability test results was proposed. The average gloss retention was determined using the gloss retention obtained from the accelerated weatherability test. The dispersion for the average gloss retention showed the regional differences. The gloss retention was estimated by a probabilistic model using the average gloss retention and standard deviation obtained from the experimental results. Consequently, the obtained experimental results were almost within the significance level of $5 \%$.

Finally, the standard deterioration of the gloss retention for each resin type of the coating materials was also analyzed. The standard degradation progress of gloss retention and this definition enabled to calculate the service life of each resin type. The results showed that the weatherability types 1,2, and three regulated in JIS A 6909 were equivalent to the service lives of fluorine, urethane, and acrylic resins respectively. The estimation results correlated with the empirical service life of the coating materials. 